\title{
Nano Cu-catalyzed efficient and selective reduction of nitroarenes under combined microwave and ultrasound irradiation
}

\author{
Huangdi Feng ${ }^{1,2,3}$, Yuan Li $i^{1}$, Shengji Lin ${ }^{1}$, Erik V Van der Eycken ${ }^{2}$ and Gonghua Song ${ }^{1 *}$
}

\begin{abstract}
In situ preparation of copper nanoparticles from a copper acetate precursor and its application as an efficient catalyst for the selective reduction of aromatic nitro compounds with hydrazine hydrate under combined microwave and ultrasound irradiation were described in detail. The results reveal the synergetic effect of microwave and ultrasound on the synthesis of copper nanoparticles, and formation of various amino derivatives.
\end{abstract}

Keywords: Microwave, Ultrasound, Nanoparticle, Reduction, Nitroarene

\section{Introduction}

From the viewpoint of environmentally benign and sustainable chemistry, there has been an increasing interest in the search for more sustainable chemical processes during the last decade [1,2]. Based on this context, the use of efficient synthetic method, nontoxic chemicals, and benign solvents, is the most valuable feature for the design of a "ideal" chemical protocol. Recently, microwave (MW) and ultrasound (US) technologies have been widely adopted as important synthetic methods in modern organic chemistry, owing to the fact that these technologies can usually reduce the reaction time, minimize energy consumption and in certain cases, increase the yield and selectivity of product [3-6].

Catalytic reduction of aromatic nitro compounds remains appealing because it is widely employed in numerous syntheses of intermediates and final products throughout the dyes, agricultural chemicals, pharmaceuticals and materials both in the laboratory and in industry [7-9]. Although many synthetic routes have been reported for the preparation of anilines from the corresponding aromatic nitro compounds [10-14], there is still necessary for the development of cost-effective catalysts with high activity in particular $\mathrm{Fe}-[15]$ and $\mathrm{Cu}$-catalyzed [16] protocol. Recently, much attention has been attracted

\footnotetext{
* Correspondence: ghsong@ecust.edu.cn

${ }^{1}$ Shanghai Key Laboratory of Chemical Biology, East China University of Science and Technology, 130 Meilong Road, Shanghai 200237, P. R. China Full list of author information is available at the end of the article
}

to the metal nanoparticles catalysts which have revealed high catalytic activities that far exceed those of conventional homogeneous catalysts, owing to their extremely small dimensions and huge special surface $[17,18]$. A few procedures involving hydrogenation of nitrobenzene into aniline catalyzed by metal Pt [19-22], Ru [23], Au [24-26] and $\mathrm{Rh}$ [27] nanoparticles have been demonstrated. Pal et al. obtained amino derivatives by the reduction of aromatic nitro compounds with $\mathrm{NaBH}_{4}$ catalyzed by coinage of metal nanoparticles $(\mathrm{Cu} / \mathrm{Ag} / \mathrm{Au})$ [28]. Wen et al. studied the catalytic transfer hydrogenation of aromatic nitro compounds in presence of polymer-supported nano-amorphous Ni-B catalyst [29]. Among the pioneering works of $\mathrm{Cu}$ nanoparticles [30-34] emerged as a promising catalyst for organic synthesis, Saha and Ranu [35] reported the reduction of nitro-compounds catalyzed by nano copper particles, however, synthesis required high stoichiometric ratio of copper nanoparticles (3 equiv.) and excess reductant (5 equiv.) to nitro-compounds, long reaction time (8-12 hours) and argon protection.

As our continuing efforts on microwave and ultrasoundassisted reaction [36-40], we found that combined microwave and ultrasound irradiation (CMUI) could strongly promote the nano $\mathrm{Cu}$-catalyzed reduction of aromatic nitro compounds due to its simultaneous enhancement on heat and mass transfer. High reaction rate, low dosage of catalyst and excellent yields were achieved via a chemoselective reduction of aromatic nitro compounds with hydrazine hydrate under CMUI. 

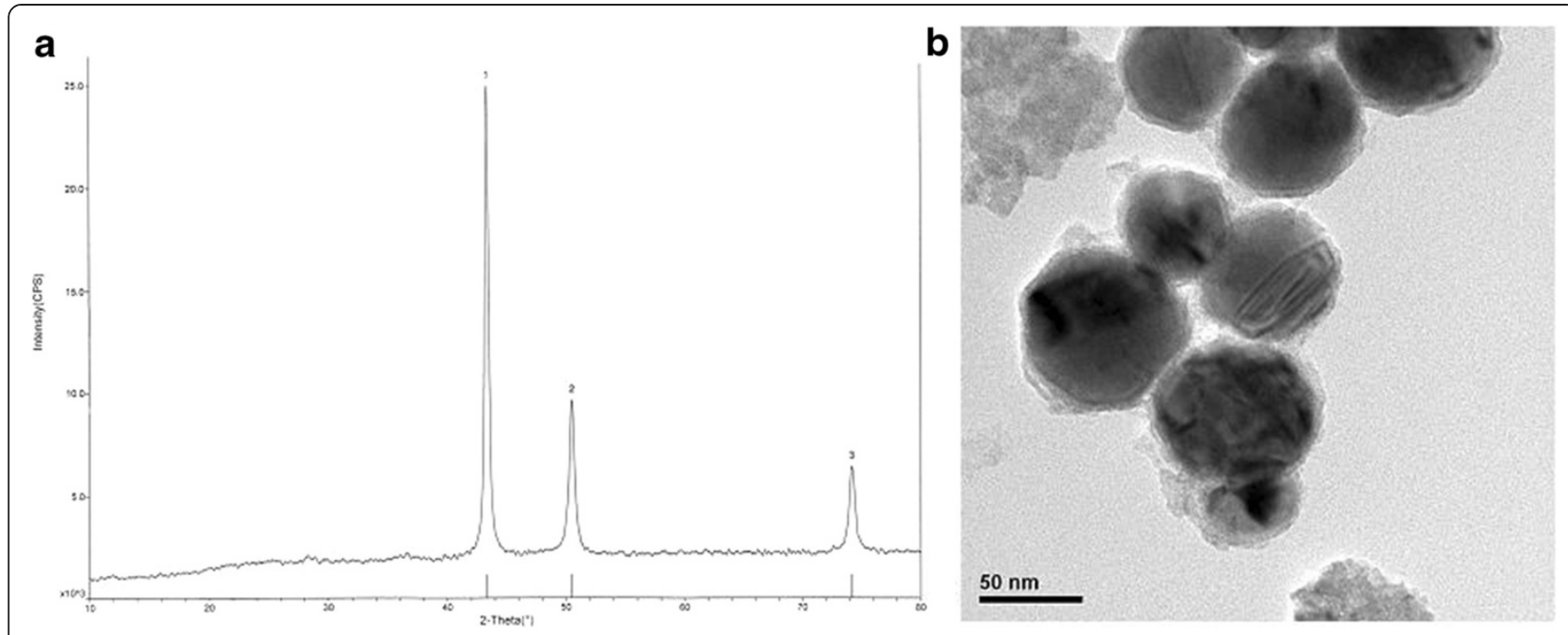

Figure 1 XRD pattern (a) and TEM images (b) of $\mathrm{Cu}$ nanoparticles.

\section{Results and discussion}

As stated in the literature [41,42], the initial copper nanoparticles were generated via a reduction of copper acetate $(1 \mathrm{mmol})$ with hydrazine hydrate (2 equiv) in ethylene glycol $(8 \mathrm{~mL})$ under combined irradiation of MW: $100 \mathrm{~W}$ maximum power and US: $50 \mathrm{~W}$ at 120 $125^{\circ} \mathrm{C}$ for $5 \mathrm{~min}$. Characterization of the copper nanoparticles were investigated by X-ray diffraction (XRD) and transmission electron microscopy (TEM). All the peaks on the XRD pattern can be readily indexed to pure copper (JCPDS file No. 04-0836) as shown in Figure 1(a). TEM image of the catalyst exhibited that the spherical nanoparticles dispersed very well (Figure 1(b)). The $\mathrm{Cu}$ nanoparticles were then employed to catalyze the reduction of 1a with hydrazine hydrate. The desired product aniline $2 \mathbf{a}$ was obtained in $89 \%$ yield in 3.5 minutes under CMUI (Figure 2, entry 1). Encouraged by this result, we then investigated the possibility of reducing nitrobenzene with hydrazine hydrate using $\mathrm{Cu}(\mathrm{OAc})_{2}$ as a catalyst precursor under CMUI. 97\% yield of 2a was formed (Figure 2, entry 2), and $\mathrm{Cu}$ nanoparticles were obtained by centrifuging and washing with ethanol. Nevertheless, the yield of $2 \mathbf{a}$ greatly reduced to $72 \%$ applying this reused $\mathrm{Cu}$ nanoparticle catalyst (Figure 2, entry 3). The activity decrease of catalyst was owing to the agglomeration and increase of particle size after reuse (Figure 3). This two-step

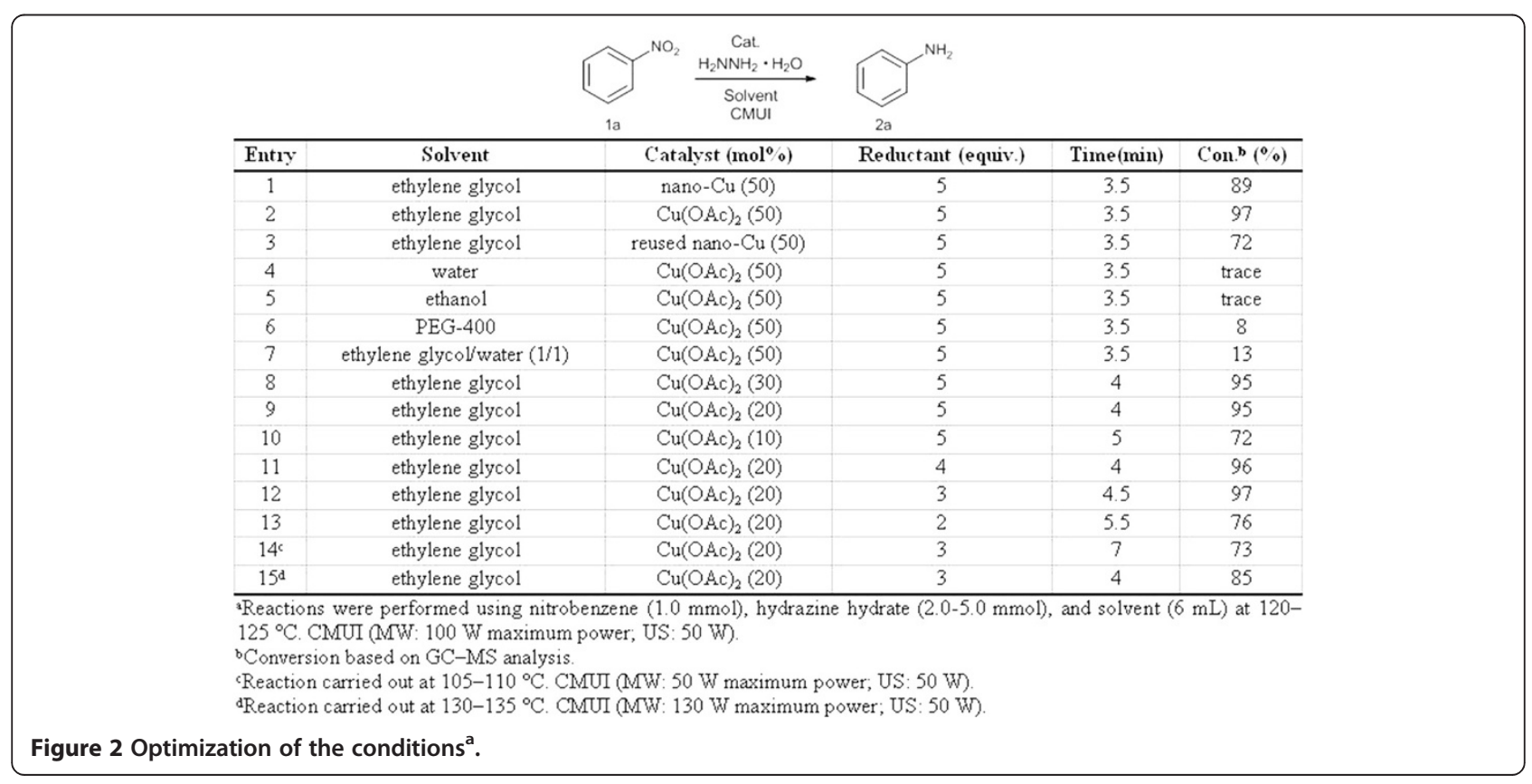




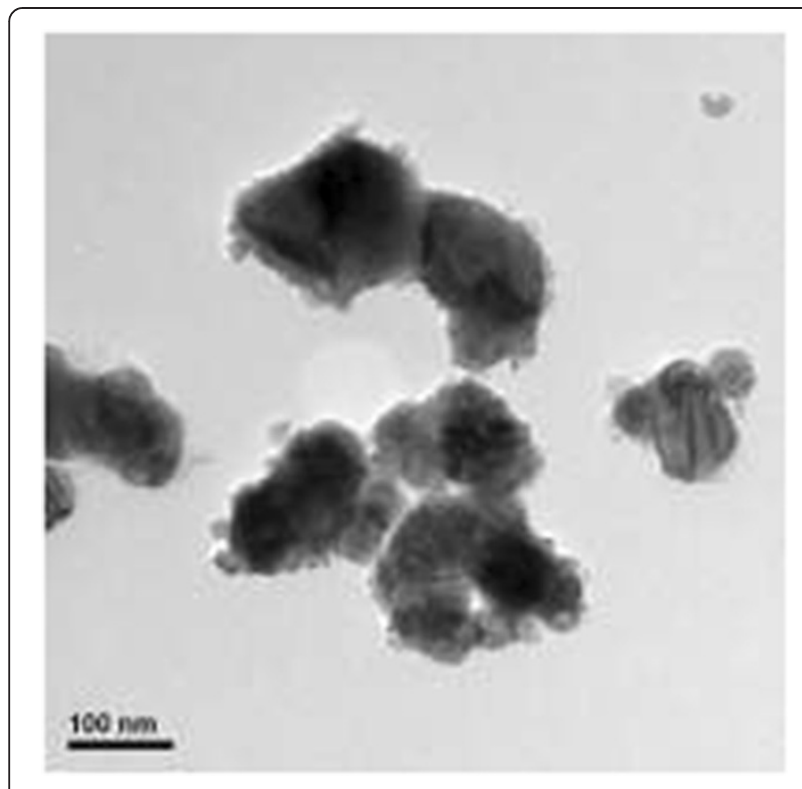

Figure 3 TEM images of reused Cu nanoparticles.

domino reaction would involve an in situ preparation of nano $\mathrm{Cu}$ catalyst followed by reduction of nitrobenzene. We subsequently examined various solvents under CMUI in the presence of $50 \mathrm{~mol} \% \mathrm{Cu}(\mathrm{OAc})_{2}$ (Figure 2, entries 4-7). None of the solvents other than ethylene glycol could give a satisfactory. This is mainly due to the fact that the reduction of simple copper salts usually tend to stop at the $\mathrm{Cu}_{2} \mathrm{O}$ stage in the presence of a number of oxygenous water without protective agents, the di-OH group of ethylene glycol is probable a stabilizer of $\mathrm{Cu}^{2+}$ in aqueous and prevents the agglomeration and growth of nanoparticles [43]. Among the concentration of $\mathrm{Cu}$ $(\mathrm{OAc})_{2}$ (Figure 2, entries 8-10) and hydrazine hydrate (Figure 2, entries 11-13) tested, $20 \mathrm{~mol} \% \mathrm{Cu}(\mathrm{OAc})_{2}$ and 3 equiv. hydrazine hydrate seemed to be the most efficient condition for this reaction. A lower reaction temperature of $105-110^{\circ} \mathrm{C}$ with relatively longer reaction time reduced the yield of the amine 2a to 73\% (Figure 2, entries 14), while increasing the temperature to $130-135^{\circ} \mathrm{C}$ also resulted in a decreased yield of $85 \%$ (Figure 2, entry 15).

Having optimized the conditions in hand (Figure 2, entry 12), we next evaluated the scope of the procedure by varying aromatic nitro compounds. The results shown in Figure 4 indicated that all reactions proceeded very smoothly (yields: 89-99\%) and quickly (shorter than $6.5 \mathrm{~min}$ ) under CMUI. Both electron-rich and electrondeficient aromatic nitro compounds $\mathbf{1}$ provided the desired product $\mathbf{2}$ in good yields. Substantial steric hindrance to the reduction was tolerated (Figure 4, entries 2, 5 and 10). Moreover, it is noteworthy that the dehalogenation was successfully avoided during the progress of the catalytic reduction of aromatic nitro compounds to the corresponding anilines under reaction conditions (Figure 4, entries 6-10) [44]. The chemoselective reduction was also observed in the case of $m$-dinitrobenzene (Figure 4 , entry 11), where one nitro group remained intact. The extremely efficient dielectric heating along with intensive mass transfer in heterogeneous systems resulted in dramatic reaction rate enhancement, and the highly catalytic activity of in situ preparation of nano $\mathrm{Cu}$ made the reduction reaction more efficient with lower amount of catalyst $(20 \mathrm{~mol} \%)$ and hydrogen source (3 equiv.).

To investigate the action of CMUI, we evaluated the reduction of nitrobenzene 1a with hydrazine hydrate in

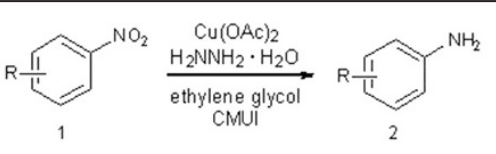

\begin{tabular}{l|c|c|c|c}
\hline Entry & $\mathrm{R}=$ & Time (min) & Product 2 & Yield $^{b}(\mathbf{\%})$ \\
\hline 1 & $\mathrm{H}$ & 4.5 & $2 \mathrm{a}$ & 94 \\
\hline 2 & $2-\mathrm{CH}_{3}$ & 6.5 & $2 \mathrm{~b}$ & 90 \\
\hline 3 & $3-\mathrm{CH}_{3}$ & 4 & $2 \mathrm{c}$ & 96 \\
\hline 4 & $4-\mathrm{CH}_{3}$ & 4.5 & $2 \mathrm{~d}$ & 94 \\
\hline 5 & $2-\mathrm{OH}$ & 5.5 & $2 \mathrm{e}$ & 89 \\
\hline 6 & $3-\mathrm{Cl}$ & 4.5 & $2 \mathrm{f}$ & 93 \\
\hline 7 & $4-\mathrm{Cl}$ & 4 & $2 \mathrm{~g}$ & 95 \\
\hline 8 & $3-\mathrm{Br}$ & 4 & $2 \mathrm{~h}$ & 96 \\
\hline 9 & $4-\mathrm{F}$ & 5 & $2 \mathrm{i}$ & 93 \\
\hline 10 & $2,5-\mathrm{diCl}$ & 6 & $2 \mathrm{j}$ & 90 \\
\hline 11 & $3-\mathrm{NO}_{2}$ & 4.5 & $2 \mathrm{k}$ & $95 \mathrm{c}$ \\
\hline
\end{tabular}

aReactions were performed using aromatic nitro compounds ( $1 \mathrm{mmol})$, copper acetate $(0.2 \mathrm{mmol})$ and hydrazine hydrate $(3 \mathrm{mmol})$ in ethylene glycol $(6 \mathrm{~mL})$ at $120-125^{\circ} \mathrm{C}$ for the indicated time (monitored by TLC). CMUI (MW: $100 \mathrm{~W}$ maximum power; US: $50 \mathrm{~W}$ ).

'Isolated yields

c30 mol\% $\mathrm{Cu}(\mathrm{OAc})_{2}$ was used.

Figure $4 \mathrm{CMUI}$-assisted nano $\mathrm{Cu}$-catalysed aromatic nitro reduction ${ }^{\mathrm{a}}$. 
Table 1 Reduction of nitrobenzene using different methods ${ }^{a}$

\begin{tabular}{ccccc}
\hline Entry & Catalyst (mol\%) & Method & Time & Con. $^{\boldsymbol{b}}$ (\%) \\
\hline 1 & $\mathrm{Cu}(\mathrm{OAc})_{2}(20)$ & MW + US & $4.5 \mathrm{~min}$ & 97 \\
2 & $\mathrm{Cu}(\mathrm{OAc})_{2}(20)$ & convention heating & $12 \mathrm{~h}$ & 52 \\
3 & $\mathrm{Cu}(\mathrm{OAc})_{2}(20)$ & $\mathrm{MW}$ & $30 \mathrm{~min}$ & 83 \\
4 & $\mathrm{Cu}(\mathrm{OAc})_{2}(20)$ & US & $3 \mathrm{~h}$ & 48 \\
5 & metallic Cu (20) & MW + US & $5 \mathrm{~min}$ & 35 \\
\hline
\end{tabular}

${ }^{a}$ Reactions were performed using nitrobenzene $(1.0 \mathrm{mmol})$, hydrazine hydrate ( $3 \mathrm{mmol}$ ) and ethylene glycol $(6 \mathrm{~mL})$ at $120-125^{\circ} \mathrm{C}, \mathrm{CMUI}(\mathrm{MW}: 100 \mathrm{~W}$ maximum power; US: $50 \mathrm{~W}$ ).

${ }^{\mathrm{b}}$ Conversion based on GC-MS analysis.

the present of pre-catalyst $\mathrm{Cu}(\mathrm{OAc})_{2}$ under conventional conditions. Only $52 \%$ yield of aniline was obtained after 12 hours at $120^{\circ} \mathrm{C}$ (Table 1, entry 2). Moreover, a lower yield was obtained when using either MW or US irradiation (Table 1, entries 3,4). The viability of commercial metallic $\mathrm{Cu}$ powder as a catalyst in the reduction of nitrobenzene under CMUI (Table 1, entry 5) was also examined. Previous described enhancement of CMUI on heterogeneous system, as well as the activation of nanosize catalysts were clearly demonstrated herein.

The proposed reaction mechanism of this reduction process is shown in Scheme 1. Firstly, $\mathrm{Cu}(\mathrm{OAc})_{2}$ is reduced by hydrazine hydrate to provide activated copper nanoparticles which would react with another hydrazine hydrate resulting in the formation of $\mathrm{CuH}$. This further proceeds to generate $\mathrm{Cu}$ and hydrogen by the thermal decomposition under the CMUI. Then the nitro compound is reduced to a nitroso compound which follows to provide the hydroxylamine and finally gives rise to amine via a hydrogenation process [45].

\section{Conclusions}

In conclusion, we have presented an efficient and convenient method for the chemoselective reduction of aromatic nitro compounds catalyzed by in situ prepared $\mathrm{Cu}$ nanoparticles under combined microwave and ultrasound irradiation. It allowed us to achieve wide range of anilines bearing both electron-donating and electronwithdrawing substituents in excellent yields. The intriguing results presented herein might open a promising new approach for the efficient preparation and application of nanoparticles.

\section{Experimental}

All solvents and reagents were purchased from commercial sources and were used without prior purification. All combined microwave and ultrasound irradiation experiments were carried out in a apparatus (a professional TCMC-102 microwave apparatus (Nanjing Lingjiang Technological Development Company, China), operating at a frequency of $2.45 \mathrm{GHz}$ with continuous irradiation power from 0 to $500 \mathrm{~W}$, and a FS-250 professional ultrasound apparatus (Shanghai S. X. Ultrasonics, China), operating at a frequency of $20 \mathrm{KHz}$ with controllable irradiation power from 10 to $100 \mathrm{~W}$. The reactions were carried out in $15 \mathrm{~mL}$ two-necked Pyrex flask, placed in the microwave cavity and the tip of detachable horn should be immersed just under the liquid surface. TLC analysis was performed on aluminum backed plates SIL G/UV254. The products were purified by column chromatography and were identified by ${ }^{1} \mathrm{H}$ NMR, ${ }^{13} \mathrm{C}$ NMR spectra recorded on $400 \mathrm{MHz}$ Bruker NMR instrument and GC-MS.

\section{General experimental procedure for the peduction of nitroarenes}

A mixture of nitro compounds ( $1 \mathrm{mmol})$, copper acetate $(0.2 \mathrm{mmol})$, hydrazine hydrate $(3 \mathrm{mmol})$ and ethylene glycol $(4 \mathrm{~mL})$ was subjected to microwave-ultrasound activation condition. Then hydrazine hydrate $(3 \mathrm{mmol})$ in ethylene glycol $(2 \mathrm{~mL})$ was added and the ultrasound and microwave source are switched on successively (power level: US $50 \mathrm{~W}, \mathrm{MW} 100 \mathrm{~W}$ maximum power). The mixture was irradiated simultaneously by microwaves and ultrasound until nearly complete conversion of aromatic nitro compounds. The progress of the reactions was monitored by TLC and GC-MS. The reaction mixture was then subjected to centrifugation. After decanting the liquid, the $\mathrm{Cu}$ nanoparticles were washed with ethanol (5 mL, three times), which was combined with the decantate. Water $(10 \mathrm{~mL})$ was added to the centrifugal liquid, and the product was extracted into ethyl acetate. Evaporation of solvent and the crude product was purified by column chromatography over silica gel

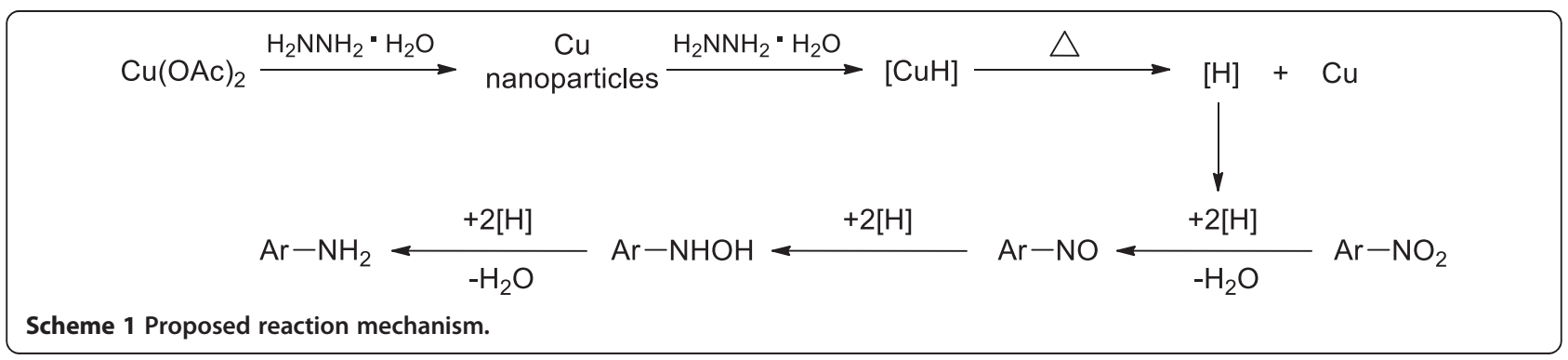


(ethyl acetate/petroleum ether $=1: 9-1: 6)$ to afford the products.

\section{Aniline (2a)}

${ }^{1} \mathrm{H}$ NMR $\left(400 \mathrm{MHz}, \mathrm{CDCl}_{3}\right): \delta 7.34(\mathrm{t}, J=7.5 \mathrm{~Hz}, 2 \mathrm{H})$, $6.95(\mathrm{~d}, J=7.4 \mathrm{~Hz}, 1 \mathrm{H}), 6.80(\mathrm{dd}, J=8.4,0.8 \mathrm{~Hz}, 2 \mathrm{H})$, 3.69 (s, 2H). ${ }^{13} \mathrm{C}$ NMR (101 $\left.\mathrm{MHz}, \mathrm{CDCl}_{3}\right): \delta 146.78$, 129.49, 118.60, 115.33. MS (GC-MS): $93\left(\mathrm{M}^{+}\right)$

\section{o-toluidine (2b)}

${ }^{1} \mathrm{H}$ NMR $\left(400 \mathrm{MHz}, \mathrm{CDCl}_{3}\right): \delta 7.25(\mathrm{t}, J=7.0 \mathrm{~Hz}, 2 \mathrm{H})$, $7.25(\mathrm{t}, J=7.0 \mathrm{~Hz}, 2 \mathrm{H}), 6.93(\mathrm{t}, J=7.4 \mathrm{~Hz}, 1 \mathrm{H}), 6.93$ $(\mathrm{t}, J=7.4 \mathrm{~Hz}, 1 \mathrm{H}), 6.87-6.77(\mathrm{~m}, 1 \mathrm{H}), 6.86-6.78(\mathrm{~m}, 1 \mathrm{H})$, 3.67 (s, 2H), $3.67(\mathrm{~s}, 2 \mathrm{H}), 2.33(\mathrm{~s}, 3 \mathrm{H}), 2.33(\mathrm{~s}, 3 \mathrm{H}) .{ }^{13} \mathrm{C}$ NMR (101 MHz, $\left.\mathrm{CDCl}_{3}\right): \delta$ 144.89, 130.64, 127.16, 122.48, 118.73, 115.13, 17.50. MS (GC-MS): $107\left(\mathrm{M}^{+}\right)$

\section{$m$-toluidine (2c)}

${ }^{1} \mathrm{H}$ NMR $\left(400 \mathrm{MHz}, \mathrm{CDCl}_{3}\right): \delta 7.36-7.18(\mathrm{~m}, 1 \mathrm{H}), 6.78$ (dd, $J=16.7,7.8 \mathrm{~Hz}, 1 \mathrm{H}), 6.64$ (ddd, $J=21.0,11.0$, $10.1 \mathrm{~Hz}, 2 \mathrm{H}), 3.73$ (s, 2H), 2.43 (d, $J=34.7 \mathrm{~Hz}, 3 \mathrm{H}) .{ }^{13} \mathrm{C}$ NMR (101 MHz, $\left.\mathrm{CDCl}_{3}\right)$ : $\delta 146.77,139.21,129.36$, 119.52, 116.16, 112.50, 21.64. MS (GC-MS): $107\left(\mathrm{M}^{+}\right)$

\section{p-toluidine (2d)}

${ }^{1} \mathrm{H}$ NMR $\left(400 \mathrm{MHz}, \mathrm{CDCl}_{3}\right): \delta 7.01(\mathrm{~d}, J=8.0 \mathrm{~Hz}, 2 \mathrm{H})$, 6.69-6.62 (m, 2H), 3.49 (s, 1H), $2.29(\mathrm{~s}, 2 \mathrm{H}) .{ }^{13} \mathrm{C}$ NMR $\left(101 \mathrm{MHz}, \mathrm{CDCl}_{3}\right): \delta 143.82,129.77,127.80,115.29$, 20.47. MS (GC-MS): $107\left(\mathrm{M}^{+}\right)$

\section{2-aminophenol (2e)}

${ }^{1} \mathrm{H}$ NMR (400 MHz, DMSO-d 6 ): $\delta 8.93(\mathrm{~s}, 1 \mathrm{H}), 6.63(\mathrm{dd}$, $J=7.7,1.3 \mathrm{~Hz}, 1 \mathrm{H}), 6.55(\mathrm{dtd}, J=9.1,7.7,1.6 \mathrm{~Hz}, 2 \mathrm{H})$, 6.45-6.32 (m, 1H), $4.46(\mathrm{~s}, 2 \mathrm{H}) .{ }^{13} \mathrm{C}$ NMR $(101 \mathrm{MHz}$, DMSO- $\left.\mathrm{d}_{6}\right): \delta 143.93,136.49,119.46,116.38,114.39$, 114.31. MS (GC-MS): $109\left(\mathrm{M}^{+}\right)$

\section{3-chlorobenzenamine (2f)}

${ }^{1} \mathrm{H}$ NMR $\left(400 \mathrm{MHz}, \mathrm{CDCl}_{3}\right): \delta 7.11(\mathrm{t}, J=8.0 \mathrm{~Hz}, 1 \mathrm{H})$, 6.86-6.74 (m, 1H), $6.69(\mathrm{t}, J=2.1 \mathrm{~Hz}, 1 \mathrm{H}), 6.56(\mathrm{ddd}$, $J=8.1,2.2,0.8 \mathrm{~Hz}, 1 \mathrm{H}), 3.71(\mathrm{~s}, 2 \mathrm{H}) .{ }^{13} \mathrm{C}$ NMR $(101 \mathrm{MHz}$, $\left.\mathrm{CDCl}_{3}\right): \delta 147.86,134.79,130.46,118.41,114.98,113.39$. MS (GC-MS): $127\left(\mathrm{M}^{+}\right)$

\section{4-chlorobenzenamine (2g)}

${ }^{1} \mathrm{H}$ NMR $\left(400 \mathrm{MHz}, \mathrm{CDCl}_{3}\right): \delta 7.17-7.08(\mathrm{~m}, 2 \mathrm{H})$, 6.68-6.57 (m, 2H), 3.57 (s, 2H).

${ }^{13} \mathrm{C}$ NMR (101 MHz, $\left.\mathrm{CDCl}_{3}\right): \delta$ 145.00, 129.12, 123.11, 116.26. MS (GC-MS): $127\left(\mathrm{M}^{+}\right)$

\section{3-bromobenzenamine (2h)}

${ }^{1} \mathrm{H}$ NMR $\left(400 \mathrm{MHz}, \mathrm{CDCl}_{3}\right): \delta 7.05(\mathrm{t}, J=8.0 \mathrm{~Hz}, 1 \mathrm{H})$, 6.93 (ddd, $J=7.9,1.7,0.9 \mathrm{~Hz}, 1 \mathrm{H}), 6.85(\mathrm{t}, J=2.0 \mathrm{~Hz}, 1 \mathrm{H})$, 6.60 (ddd, $J=8.0,2.2,0.9 \mathrm{~Hz}, 1 \mathrm{H}), 3.73(\mathrm{~s}, 2 \mathrm{H}) .{ }^{13} \mathrm{C}$ NMR $\left(101 \mathrm{MHz}, \mathrm{CDCl}_{3}\right): \delta 148.06,130.80,123.08,121.31$, 117.86, 113.84. MS (GC-MS): $170\left(\mathrm{M}^{+}\right)$

\section{4-fluorobenzenamine (2i)}

${ }^{1} \mathrm{H}$ NMR $\left(400 \mathrm{MHz}, \mathrm{CDCl}_{3}\right): \delta$ 6.99-6.80 (m, 2H), 6.69-6.55 (m, 2H), 3.56 (s, 2H). ${ }^{13} \mathrm{C}$ NMR (101MHz, $\left.\mathrm{CDCl}_{3}\right)$ : $\delta$ 157.54, 155.21, 142.70, 142.68, 116.15, 116.08, 115.77, 115.55. MS (GC-MS): 111( $\left.\mathrm{M}^{+}\right)$

\section{2,5-dichlorobenzenamine (2j)}

${ }^{1} \mathrm{H}$ NMR $\left(400 \mathrm{MHz}, \mathrm{CDCl}_{3}\right): \delta 7.17(\mathrm{~d}, J=8.5 \mathrm{~Hz}, 1 \mathrm{H})$, $6.77(\mathrm{~d}, J=2.3 \mathrm{~Hz}, 1 \mathrm{H}), 6.68(\mathrm{dd}, J=8.5,2.4 \mathrm{~Hz}, 1 \mathrm{H})$, 4.08 (s, 2H). ${ }^{13} \mathrm{C}$ NMR (101 MHz, $\left.\mathrm{CDCl}_{3}\right): \delta 143.82$, 133.12, 130.19, 118.84, 117.44, 115.37. MS (GC-MS): $162\left(\mathrm{M}^{+}\right)$

\section{3-nitrobenzenamine (2k)}

${ }^{1} \mathrm{H}$ NMR $\left(400 \mathrm{MHz}, \mathrm{CDCl}_{3}\right): \delta 7.64-7.53(\mathrm{~m}, 1 \mathrm{H})$, 7.53-7.46 (m, 1H), 7.36-7.20 (m, 1H), 6.96 (ddd, $J=8.0$, 2.3, $0.8 \mathrm{~Hz}, 1 \mathrm{H}), 4.03$ (s, 2H). ${ }^{13} \mathrm{C}$ NMR $\left(101 \mathrm{MHz}, \mathrm{CDCl}_{3}\right)$ : $\delta$ 149.24, 147.48, 129.91, 120.64, 113.11, 109.01. MS (GC-MS): $138\left(\mathrm{M}^{+}\right)$

\section{Competing interests}

The authors declare that they have no competing interests.

\section{Authors' contributions}

HDF and GHS designed the research with HDF and YL performing the experiments; HDF and SJL analyzed the data; HDF, EVDE and GHS wrote the paper, and all authors read and approved the final manuscript.

\section{Acknowledgements}

Financial support for this work from the National Basic Research Program of China (973 Program) (Grant 2010CB126101) and the Shanghai Leading Academic Discipline Project (Project Number: B507) are gratefully acknowledged.

\section{Author details}

${ }^{1}$ Shanghai Key Laboratory of Chemical Biology, East China University of Science and Technology, 130 Meilong Road, Shanghai 200237, P. R. China. ${ }^{2}$ Department of Chemistry, Laboratory for Organic \& Microwave-Assisted Chemistry (LOMAC), Katholieke Universiteit Leuven, Celestijnenlaan 200F, B-3001 Leuven, Belgium. ${ }^{3}$ College of Chemistry and Chemical Engineering, Shanghai University of Engineering Science, 333 Longteng Road, Shanghai 201620, P. R. China.

Received: 8 March 2014 Accepted: 2 June 2014

Published: 18 June 2014

\section{References}

1. Clark JH: Green chemistry: challenges and opportunities. Green Chem 1999, 1:1-8.

2. Li CJ, Anastas PT: Green Chemistry: present and future. Chem Soc Rev 2012, 41:1413-1414.

3. Appukkuttan P, Mehtaa VP, Van der Eycken EV: Microwave-assisted cycloaddition reactions. Chem Soc Rev 2010, 39:1467-1477.

4. Kappe CO, Van der Eycken EV: Click chemistry under non-classical reaction conditions. Chem Soc Rev 2010, 39:1280-1290.

5. Cracotto G, Cintas P: Power ultrasound in organic synthesis: moving cavitational chemistry from academia to innovative and large-scale applications. Chem Soc Rev 2006, 35:180-196.

6. Polshettiwar V, Varma RS: Microwave-Assisted Organic Synthesis and Transformations using Benign Reaction Media. Acc Chem Res 2008, 41:629-639. 
7. Tafesh AM, Weiguny J: A Review of the Selective Catalytic Reduction of Aromatic Nitro Compounds into Aromatic Amines, Isocyanates, Carbamates, and Ureas Using CO. Chem Rev 1996, 96:2035-2052.

8. Li F, Cui JN, Qian XH, Zhang R, Xiao Y: Highly chemoselective reduction of aromatic nitro compounds to the corresponding hydroxylamines catalysed by plant cells from a grape. Chem Commun 2005, 43:1901-1903.

9. He DP, Shi H, Wu Y, Xu BX: Synthesis of chloroanilines: selective hydrogenation of the nitro in chloronitrobenzenes over zirconia-supported gold catalyst. Green Chem 2007, 9:849-951.

10. Liang M, Wang $X$, Liu H, Wang J: Excellent catalytic properties over nanocomposite catalysts for selective hydrogenation of halonitrobenzenes. J Catal 2008, 255:335-342.

11. Chandrasekhar S, Prakash SJ, Rao CL: Poly(ethylene Glycol) (400) as Superior Solvent Medium against lonic Liquids for Catalytic Hydrogenations with PtO2. J Org Chem 2006, 71:2196-2199.

12. Shi Q, Lu R, Lu L, Fu X, Zhao D: Efficient Reduction of Nitroarenes over Nickel-Iron Mixed Oxide Catalyst Prepared from a Nickel-Iron Hydrotalcite Precursor. Adv Synth Catal 2007, 349:1877-1881.

13. Mandal PK, McMurray JS: Pd - C-Induced Catalytic Transfer Hydrogenation with Triethylsilane. J Org Chem 2007, 72:6599-6601.

14. Rahaim RJ Jr, Maleczka REJ: Pd-Catalyzed Silicon Hydride Reductions of Aromatic and Aliphatic Nitro Groups. Org Lett 2005, 7:5087-5090.

15. Wienhöfer G, Sorribes I, Boddien A, Westerhaus F, Junge K, Junge H, Llusar R, Beller M: General and Selective Iron-Catalyzed Transfer Hydrogenation of Nitroarenes without Base. J Am Chem Soc 2011, 133:12875-12879.

16. Sharma U, Kumar P, Kumar N, Kumar V, Singh B: Highly Chemo- and Regioselective Reduction of Aromatic Nitro Compounds Catalyzed by Recyclable Copper(II) as well as Cobalt(II) Phthalocyanines. Adv Synth Catal 2010, 352:1834-1840.

17. Song XY, Sun SX, Zhang WM, Yin ZL: A method for the synthesis of spherical copper nanoparticles in the organic phase. J Colloid Interface Sci 2004, 273:463-469.

18. Mitudome T, Arita S, Mori H, Mizugaki T, Jitsukawa K, Kaneda K: Supported Silver-Nanoparticle-Catalyzed Highly Efficient Aqueous Oxidation of Phenylsilanes to Silanols. Angew Chem Int Ed 2008, 47:7938-7940.

19. Min Kl, Choi JS, Chung YM, Ahn WS, Ryoo R, Lim PK: p-Aminophenol synthesis in an organic/aqueous system using Pt supported on mesoporous carbons. Appl Catal A Gen 2008, 337:97-140.

20. Takasaki M, Motoyama Y, Higashi K, Yoon SH, Mochida I, Nagashima H: Chemoselective Hydrogenation of Nitroarenes with Carbon Nanofiber-Supported Platinum and Palladium Nanoparticles. Org Lett 2008, 10:1601-1604.

21. Wang F, Liu JH, Xu XL: Layered material $Y$-ZrP supported platinum catalyst for liquid-phase reaction: a highly active and selective catalyst for hydrogenation of the nitro group in para-chloronitrobenzene. Chem Commun 2008, 46:2040-2042

22. Motoyamal Y, Lee YJ, Tsuji K, Yoon SH, Mochida I, Nagashima H: Platinum Nanoparticles Supported on Nitrogen-doped Carbon Nanofibers as Efficient Poisoning Catalysts for the Hydrogenation of Nitroarenes. ChemCatChem 2011, 3:1578-1581.

23. Liu MH, Yu WY, Liu HF: Selective hydrogenation of o-chloronitrobenzene over polymer-stabilized ruthenium colloidal catalysts. J Mol Catal A Chem 1999, 138:295-303.

24. Boronat P, Concepción A, Corma S, González F, Serna IP: A Molecular Mechanism for the Chemoselective Hydrogenation of Substituted Nitroaromatics with Nanoparticles of Gold on TiO2 Catalysts: A Cooperative Effect between Gold and the Support. J Am Chem Soc 2007, 129:16230-16237.

25. Lou XB, He L, Qian Y, Liu YM, Cao Y, Fan KN: Highly Chemo- and Regioselective Transfer Reduction of Aromatic Nitro Compounds using Ammonium Formate Catalyzed by Supported Gold Nanoparticles. Adv Synth Catal 2011, 353:281-286.

26. Corma A, Serna P: Chemoselective Hydrogenation of Nitro Compounds with Supported Gold Catalysts. Science 2006, 313:332-334.

27. Luo PF, Xu KL, Zhang R, Huang L, Wang J, Xing WH, Huang J: Highly efficient and selective reduction of nitroarenes with hydrazine over supported rhodium nanoparticles. Catal Sci Technol 2012, 2:301-304.

28. Pradhan N, Pal A, Pal T: Catalytic Reduction of Aromatic Nitro Compounds by Coinage Metal Nanoparticles. Langmuir 2001, 17:1800-1802.

29. Wen HL, Yao KS, Zhang YD, Zhou ZM, Kirschning A: Catalytic transfer hydrogenation of aromatic nitro compounds in presence of polymer-supported nano-amorphous Ni-B catalyst. Catal Commun 2009, 10:1207-1211.

30. Ranu BC, Saha A, Jana R: Microwave-Assisted Simple and Efficient Ligand Free Copper Nanoparticle Catalyzed Aryl-Sulfur Bond Formation. Adv Synth Catal 2007, 349:2690-2696

31. Bhadra S, Saha A, Ranu BC: One-pot copper nanoparticle-catalyzed synthesis of S-aryl- and S-vinyl dithiocarbamates in water: high diastereoselectivity achieved for vinyl dithiocarbamates. Green Chem 2008, 10:1224-1230.

32. Kidwai M, Bansal V, Saxena A, Aerry S, Mozumdar S: Cu-Nanoparticles: efficient catalysts for the oxidative cyclization of Schiffs' bases. Tetrahedron Lett 2006, 47:8049-8053.

33. Singh $P$, Katyal A, Kalra R, Chandra R: Copper nanoparticles in an ionic liquid: an efficient catalyst for the synthesis of bis-(4-hydroxy-2-oxothiazolyl) methanes. Tetrahedron Lett 2008, 49:727-730.

34. Ahammed S, Saha A, Ranu BC: Hydrogenation of Azides over Copper Nanoparticle Surface Using Ammonium Formate in Water. J Org Chem 2011, 76:7235-7239.

35. Saha A, Ranu BC: Highly Chemoselective Reduction of Aromatic Nitro Compounds by Copper Nanoparticles/Ammonium Formate. J Org Chem 2008, 73:6867-6870.

36. Peng $\mathrm{YQ}$, Song $\mathrm{GH}$ : Simultaneous microwave and ultrasound irradiation: A rapid synthesis of hydrazides. Green Chem 2001, 3:302-304.

37. Peng $Y Q$, Dou RL, Song GH: Surface cleaning under combined microwave and ultrasound irradiation: flash synthesis of $4 \mathrm{H}$-pyrano[2,3-c]pyrazoles in aqueous media. Green Chem 2006, 8:573-575.

38. Feng HD, Li Y, Van der Eycken EV, Peng YQ, Song GH: Synthesis of polysubstituted pyridines under combined microwave and ultrasound irradiation: $\mathrm{K}_{2} \mathrm{CO}_{3}$-promoted tandem addition/cyclization/hydrogen shift process. Tetrahedron Lett 2012, 53:1160-1162.

39. Feng HD, Lin SJ, Wang JY, Song GH, Peng YQ: Aqueous heterogeneous synthesis of polysubstituted 2,6-dicyanoanilines via combined microwave and ultrasound-assisted multicomponent reaction. Green Process Synth 2012, 1:463-468.

40. Feng HD, Ying XL, Peng YQ, Van der Eycken EV, Liu CD, Zhao SS, Song GH: $\mathrm{FeCl}_{3}$ - promoted synthesis of 1,3,4-thiadiazoles under combined microwave and ultrasound irradiation in water. Monatsh Chem 2013, 144:681-686.

41. Zhu HT, Zhang CY, Yin YS: Novel synthesis of copper nanoparticles: influence of the synthesis conditions on the particle size. Nanotechnology 2005, 16:3079-3083.

42. Zhu HT, Zhang CY, Yin YS: Rapid synthesis of copper nanoparticles by sodium hypophosphite reduction in ethylene glycol under microwave irradiation. J Crystal Growth 2004, 270:722-728.

43. Park BK, Jeong S, Kim D, Moon J, Lim S, Kim JS: Synthesis and size control of monodisperse copper nanoparticles by polyol method. J Colloid Interface Sci 2007, 311:417-424.

44. Jin ZH, Wang XY, Wang ST, Li D, Lu GZ: The effect of triethylamine on the hydrodechlorination of chlorophenols on $\mathrm{Pd} / \mathrm{C}$ at low temperature. Catal Commun 2009, 10:2027-2030.

45. Corma A, Concepcin P, Serna P: A different reaction pathway for the reduction of aromatic nitro compounds on gold catalysts. Angew Chem Int Ed 2007, 46:7266-7269.

doi:10.1186/2043-7129-2-14

Cite this article as: Feng et al:: Nano Cu-catalyzed efficient and selective reduction of nitroarenes under combined microwave and ultrasound irradiation. Sustainable Chemical Processes 2014 2:14. 